\title{
The Meanings of "Kanashii" and "Kurushii" from the Perspective of Kanji Writing and Their Uses in Japanese Sentences
}

\author{
Ngurah Indra Pradhana \\ Japanese Department Faculty of Arts Udayana University \\ Bali, Indonesia \\ Indra_pradana@unud.ac.id
}

\begin{abstract}
This research is entitled "The Meanings Of "Kanashii" And "Kurushii" From The Perspective Of Kanji Writing And Their Uses In Japanese Sentences." This title was chosen as a research topic because it is still rare to conduct their research that analyzes the meaning of adjectives, especially the synonymous adjective by reviewing the formation of kanji. There are not many people know, especially for Japanese language learners and is very interesting to stimulate new research variations. This research is useful to introduce to the audience the culture and mindset of Japanese society from scratch kanji. Besides, through this research, we can know the use of two words that are synonymous with the exact aspects of their meaning with a review of the formation of kanji. The method used in this study consists of a method of referring to data collection by tapping techniques. In the next practice, this tapping technique is followed by advanced techniques in the form of techniques of recording and techniques of uninvolved conversation technique. The technique of note is to record things that are considered important. The method used to analyze the data is the method of agih (distribution method). The last stage is the presentation of the results of analysis by using formal and informal methods. It is done so that the readers understand the research results more clearly. The theory used in this research is about kanji and its formation, synonym theory, and theory of contextual meaning. With these theories, the results to be obtained from this research is to know the pattern of kanji formation 悲しい "kanashii" and 苦しい "kurushii" and the use of the word 悲しい "kanashii" and 苦しい "kurushii" in Japanese sentence. Besides, the additional results of this study are that the readers are given differences in the use of two synonyms words in Japanese with cultural nuances they have.
\end{abstract}

Keywords: Kanji, Synonyms, Kanashii, Kurushii

\section{INTRODUCTION}

Kanji is one of the types of letters or characters used in Japanese and has its features, especially in how to read and how to write. This letter is very important in Japanese because it can express meaning. Takebe (1982) mentions kanji including Hyoo i moji (表意 文字) since each letter expresses meaning. For the Japanese, just by glimpsing a kanji, he will know the meaning of the kanji even though he does not know how to read it. Takebe further emphasized that in the use of kanji, we can not arbitrarily but must give priority to the meaning of each kanji, because it determines the meaning of kanji in question. In relation to the above, Takebe adds that a unique and important thing in the kanji is that in each kanji it has three basic elements: 音, 形, 義 (on, kei, gi = sound, shape, and meaning) this element is not owned in other letters, especially the letters of the alphabet included in the hyoo on moji. It has been widely recognized by Japanese language learners and not a few who feel that Kanji is a difficult field to learn in Japanese, especially by Japanese language learners who have no background "kanji culture", which in Japanese is called hikanjiken (非 漢字 圏), it is caused by many factors such as enough number of kanji to remember, how to read varied kanji, hitsujun (筆順 = how to write it) that must be paid attention, as well as kanji knowledge which includes bushu (部首 = the kanji part that determines the meaning ) And rikusho (六書 $=$ the formation and use of kanji). 


\section{RESEARCH METHOD}

Methods and techniques are two tools that are very important to get the result of a study. A method is a way of approaching, observing, analyzing, and explaining a phenomenon (Kridalaksana, 2011: 153). While the technique is how to implement the method (Sudaryanto, 1993: 9). The following three stages are the steps that researchers do to get the final result of the data. The three stages are data collection, data analysis, and presentation of the results of the data analysis.

\subsection{Method and Technique Of Data Collection}

In the data collection stage, listening method refer. The method is a method to obtain data by listening to the use of language. This method has a basic technique in the form of tapping techniques. Tapping techniques referred to as basic techniques in the method refer to the essence of the tampering is realized by tapping both the oral and written data (Mahsun: 2005).

In this case, researchers tend to use this method to obtain written data. In the next practice, this tapping technique is followed by advanced techniques in the form of techniques of recording and techniques of uninvolved conversation technique. The note-taking technique of note is to record things that are considered important. In the uninvolved conversation technique, researchers only act as observers of language use.

The way of data collection is done by literature study, which is data collection through various written sources in the Japanese language. The application of this method in this research is to listen to the use of vocabulary using Kanashii and Kurushii kanji in the predefined primary data sources, in the form of Japanese dictionaries, novels, magazines, and books. The technique used is the recording technique. The data that has been found is recorded directly into the computer.

\subsection{Method and Technique Of Analyzing Data}

Stages of analyzing the data is a very decisive stage. At this stage the data already obtained will be analyzed. The method used to analyze the data is the method of agih (distribution method). Research targets of such methods, such as words (disbelief, prepositions, adverbs, etc.), syntactic functions (subject, object, predicate, etc.), clauses, syllabisms, pitches, and others. (Sudaryanto, 1993: 16).

The analysis is done after all the data has been collected. Data are analyzed by their structure, meaning, and usage. To analyze the research data using the descriptive method that describes the elements attached to the vocabulary Kanashii and Kurushii. The technique used is to analyze the structure, meaning, and life of its users.

\subsection{Method and Technique Of Presenting The Results Of} Analysis

The presentation stage is an attempt the researcher presents in the form of "report" written things that have resulted from the work of analysis, especially rules (Sudaryanto, 1993: 7).
In this research, the result of data analysis is presented by using an informal method, that is explaining data by way of describing all elements descriptively.

\section{RESULTS AND ANALYSIS}

Takebe (1982) reveals that in each kanji it has three basic elements: 音, 形, 義 (on, kei, gi = sound, shape, and meaning). These elements include the hitsujun (筆順 $=$ how to write it), the kanji knowledge that includes the bushu (部 首 = the kanji part that determines the meaning) and rikusho (六書 $=$ the formation and use of kanji). All aspects of the kanji are applied in kaka kanashii and kurushii following.

\subsection{Hitsujun （筆順 $=$ How to write it）}

According to Fujiwara in Rosita (1990: 9), Hitsujun is a sequence of writing lines or streaks when writing kanji. The writing of this kanji must be in order correctly. Here is the sequence of kanji kanashii and kurushii.

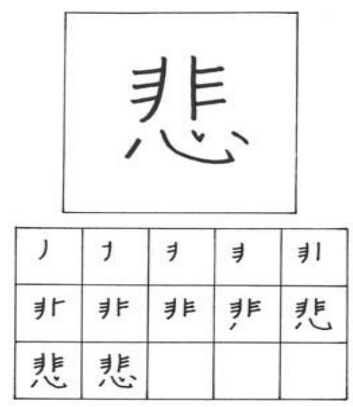

(The sequence kanji kanashii)

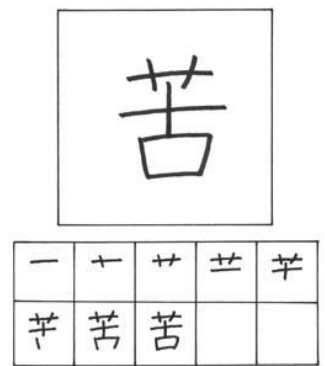

(The sequence kanji kurushii)

\subsection{Bushu （部首 = Part of Kanji That Determine} Meaning)

In kanji kanashii which becomes bushu is kanji kokoro (心) which means heart/feeling. This type of Bushu belongs to the type of bushu Ashi (脚). This type of Bushu is a bushu located at the bottom of a kanji. A part from kokoro as the basic kanji, there is also kanji hi or arazu (非) which 
implies injustice, error, negative, etc. Philosophically the meanings of the two kanji are feeling due to injustice, failure, or disappointment.

Kanji kurushii is formed from is made up of bushu type kanmuri. This type of Bushu is a bushu located at the top of a kanji. Bushu on this kanji is Kusha which in Indonesian means "grass." Besides kusha kanji, kanji kurushi also has kanji furui (古 い) which means "old." Of the two kanji, it gives meaning to kanji kurushii is a feeling of misery and tend to be painful.

\subsection{Rikusho （六書 = Formation and usage/use of kanji）}

According to Shimura (1990: 34), rikusho is classified into six parts: shookei, shiji, kai'i, keisei, tenchuu and kasha. Shookei, shiji, kai'i and keisei show the formation or ways of creating a kanji, while tenchuu and kasha indicate the use of kanji. The following kanji kurushii and kanashii in the lyrics of Japanese songs.

\subsubsection{The Use Of Kanji Kanashii (悲しい)}

\section{色あせた響さ 作られた悲しさ}

Iro aseta hibiki tsukurareta kanashisa

'In a faded voice, with made-up sadness.'

Misawa Aki - Fragment

Meaning:

The words “悲しさ” in the song lyrics show the feeling of sadness indicated by a faded voice

もう・・・悲しまずに

Mou... kanashimazuni

'So... don't be sad.'

Inosuke Tsutsumi - Bite on the Bullet

Meaning:

The words “悲しまずに” in the song lyrics have the meaning of request not to be sad again.

抜け出してって 抜け出してって

\section{悲しすぎる運命から}

Nukedashitette nukedashitette

Kanashisugiru unmeikara

Escape, escape, from this sorrowful fate'

Shimamiya Eiko - Naraku no Hana

Meaning:

The words “悲しすぎる” in the song's lyrics denote the meaning of getting rid of the fate/sadness.

\section{黒い涙流す}

\section{私には何もなくて悲しすぎて}

Kuroi namida nagasu

Watashi ni ha nanimo nakute kanashisugite

'Black tears flow

inside of me and there's nothing else; just sadness.'

Anna Tsuchiya - Kuroi Namida
Meaning:

The words “悲しすぎて” in the song lyrics show the meaning of sadness reflected by dark/black tears. 昨日読んだ物語が悲しすぎて なんとなく不安になつたわけじやないけど!

Kinou yonda monogatari ga kanashisugite Nantonaku fuan ni natta wakejanaikedo!

'Don't get me wrong! I certainly didn't feel uneasy because I read an extremely sad story yesterday!' Chata - Daisuki

Meaning:

The words “悲しすぎて” in the song lyrics denote an uneasy feeling caused not by the previous sad story.

3.3.2 The Use Of Kanji Kurushii (苦しい)

\section{会いたい気持ちで僕を 苦しませないでくれ}

Aitai kimochi de boku wo kurushimasenaidekure

'Don't make me suffer by making me miss you, would you?' Hatsune Miku - Risky Game

Meaning:

The words “苦しませないでくれ” in the song lyrics have the meaning of the request for not becoming sad but the feeling of missing something.

\section{さよならも苦しさも忘れはしない}

Sayonara mo kurushisa mo wasure ha shinai

'I won't forget the goodbyes and pains'

Vivid - Hikari

Meaning:

The words “苦しさ” in the song lyrics denote the feeling of pain and leave-taking which cannot be forgotten.

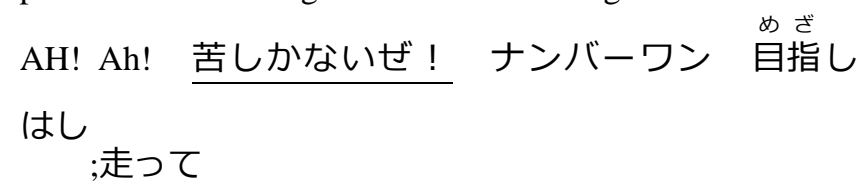

AH! Ah! Kurushikaize! Nanba-kun mezashi hashitte

'AH! Ah! No pain! Run, aiming for number one.'

ZZ - Dang Dang

Meaning:

The words “苦しかないぜ!” in the song lyrics have the meaning of not feeling sad and keep moving on to be number one/the best.

ふつうに話すのは苦しすぎるよ

Futsuu ni hanasu no ha kurushisugiruyo

'Talking to you normally is too painful.'

$\mathrm{BiBi}$ - Sakkaku Crossroads

Meaning:

The words “苦しすぎるよ” in the song lyrics show the meaning of speaking normally though it is very painful.

上手に隠してる つもりの苦しさも 


\section{全部わかってる}

Josuu ni kakushiteru tsumori no kurushisamo

Zenbu wakatteru

'And the pain you intend to hide well

I know it all.'

Fujiwara Keiji - Angel Heart

Meaning:

The words “苦しさ” in the chunks of the song lyrics have the meaning of knowing all the pains that have been hidden.

\section{CONCLUSION}

This research discusses the process of kanji formation Kanashii and Kurushii that support the creation of meaning from kanji. Also, to strengthen the meaning, Japanese sentences in the form of song lyrics using kanji kanashii and kurushii. Were also analyzed Here is the summary of the analysis process conducted in the discussion chapter. Here is the sequence of kanji kanashii and kurushii.

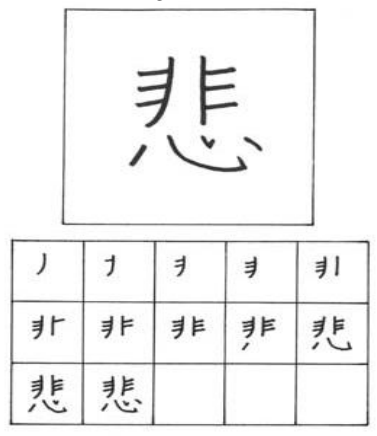

(The sequence of kanji kanashii writing)

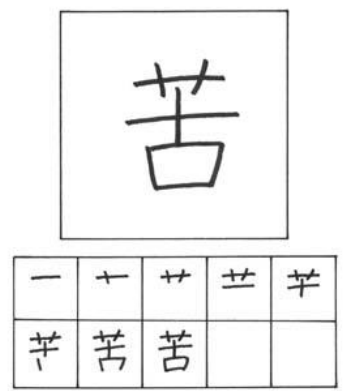

(The sequence of kanji kurushii writing)

In kanji kanashii which becomes bushu is kanji kokoro (心) which means heart/feeling. This type of Bushu belongs

to the type of bushu Ashi (脚). This type of Bushu is a bushu located at the bottom of a kanji. Besides kokoro kanji as the basic kanji, there is also kanji hi or arazu (非) which implies injustice, error, negative, etc. Philosophically the two kanji that make up the meaning of the kanashii kanji bring the meaning of a deep feeling due to injustice, failure, or disappointment.
Kanji kurushii is made up of bushu type kanmuri. This type of Bushu is a bushu located at the top of a kanji. Bushu on this kanji is Kusha which in Indonesian means "grass." Besides kusha kanji, kanji kurushi also has kanji furui (古 () which means "old." The two kanji gives meaning to kanji kurushii that is a feeling of misery and tend to be painful.

From the data of kanji kanashii and kurushii it can be concluded that the tendency of the meaning of kanashii word is sadness (sadness) whereas meaning kurushii word is misery/hurt (pain).

In its usage, kanji kanashii and kurushii are sometimes interchangeable, since the meaning they bring is almost the same which is in linguistics commonly known as a synonym. However, the two words are not interchangeable. For example, in expressing the feeling of sadness kanji kanashii is used, meanwhile, to state the feeling of hurtful or miserable kanji kurushii is preferably used.

\section{REFERENCES}

Chaer, A. 1999. Pengantar Semantik Bahasa Indonesia. Jakarta : Rineka Cipta.

Chaer, Abdul. 2007. Linguistik Umum. Jakarta: Rineka Cipta

Kridalaksana, Harimurti. 2011. Kamus Linguistik. Edisi IV. Jakarta: PT Gramedia Pustaka Utama.

Mahsun. 2005. Metode Penelitian Bahasa. Jakarta : PT. Raja Grafindo Persada.

Mitamura, Joyce Yumi dan Mitamura, Yasuko Kosaka. 1997. Let's Learn Kanji. Tokyo: Kodansha International. Ltd

Sudaryanto. 1993. Metode dan Aneka Teknik Analisis Bahasa. Yogyakarta: Duta Wacana University Press.

Shimura, Ueno. 1990. Kanji.Tokyo: Meiji Shouin

Takebe. 1982. Kanji no Youhou.Tokyo: Kadokawa Shoten

Todo, Akiyasu. 1972. Gakushuu Kanji Jiten. Tokyo : Shougakukan.

Yoshiake, Takebe.1993. Kanji wa Muzukashikunai (Kanji Isn't That Hard). Tokyo: PT Aruku. 